\title{
Study of the Translocation and Distribution of Cadmium into Bean Plants (Phaseolus vulgaris) Using Labelled Cd-109
}

\author{
Hocine Benabid ${ }^{1}$, Mohamed Fouzi Ghorab ${ }^{2}$ \\ ${ }^{1}$ Institute of Industrial Safety and Environment, University of Batna, Batna, Algeria \\ ${ }^{2}$ Faculty of Sciences, University of Annaba, Annaba, Algeria \\ Email: benabidhoc@yahoo.fr
}

Received July 5, 2013; revised August 5, 2013; accepted August 12, 2013

Copyright (c) 2013 Hocine Benabid, Mohamed Fouzi Ghorab. This is an open access article distributed under the Creative Commons Attribution License, which permits unrestricted use, distribution, and reproduction in any medium, provided the original work is properly cited.

\begin{abstract}
The motivation of this work was dictated by a concern of using bioaccumulative plant species likely to be used in the technique of bioindication. The obtained results and discussions proposed are approaches of chemist, because the mechanisms of the effect of cadmium on the various plant cells have been widely developed by several biologists. The use of labeled cadmium is important to study the uptake, the translocation and the metabolism at very low levels of this element in plants. Bean (Phaseolus vulgaris), the model chosen for the investigation, was cultivated in vermiculite for 12 days. After this period, plants were transferred into $100 \mathrm{ml}$ flasks containing nutrient solution and radioactive Cd-109 $(\gamma$, $\mathrm{t}_{1 / 2}=461.3$ days) with variable activity of: $0.05,0.1$ and 1.0 micro Currie $(\mu \mathrm{Ci})$. Samples were transferred to a growth room and left for periods of 4 and 7 days, then analyzed by the solid scintillation method. The counting was carried out for roots, stems and leaves.
\end{abstract}

Keywords: Translocation; Metabolism; Labeled Cadmium; Solid Scintillation

\section{Introduction}

The study of the transportation and translocation of cadmium in plants using the radioelement ${ }^{109} \mathrm{Cd}$ is of great importance for the follow-up of the evolution of the element into vegetable species. The extensive use of pesticides and the increase of the industrial waste generate a great concern and interest to carry out surveys on the effects of these contaminants and their influence on the environment. This is the reason why extensive research on the microbial metabolism of these contaminants has become necessary in order to preserve the environment.

By making use of radioisotopes, information can be obtained concerning the transformation implied in the formation and degradation of natural molecules in soils and the effect of these organic constituents on the fertility of soils. The other major advantage of the use of radio elements is that it allows predictions on the biodegradability and possible toxicity of a given compound to be made. The use of radio elements can be extended to organic insecticides, herbicides and other agricultural chemical products used in soil systems. The use of ra- dioactive compounds is important in order to follow the translocation, absorption and metabolism of traces of pesticides or simply of a given element. This has become possible thanks to the increasing availability of pesticides labelled with isotopes such as ${ }^{3} \mathrm{H},{ }^{14} \mathrm{C},{ }^{35} \mathrm{~S}$, ...etc [1]. Besides the environmental concerns, the use of radio elements may contribute greatly to agriculture since they can be used with the same investigative objective as in animals. Along with the determination of biodegradability and metabolism of vegetables species, their biochemistry nutrition can also be determined. The radioisotopes widely used are ${ }^{14} \mathrm{C}$ and ${ }^{3} \mathrm{H}$ with half lives of 5730 and 1226 years respectively. In this respect several other radioisotopes can also be used. To understand the mechanisms, this study made use of ${ }^{109} \mathrm{Cd}$ and ${ }^{65} \mathrm{Zn}$ in order to investigate the transport interaction of $\mathrm{Zn}$ and $\mathrm{Cd}$ to the plasmic membrane of cells in the roots of tender wheat (Triticum aestivum L.) and hard wheat (Triticum turgidum L. var. Durum) [2].

As for the use of ${ }^{109} \mathrm{Cd}$ for the determination of the evolution and translocation of $\mathrm{Cd}$ in plants, one could mention a series of studies realised by [3] who used the same 
experimental conditions, namely the use of culture solution (hydroponics) obtained results indicating that ${ }^{109} \mathrm{Cd}$ was more presented in roots than other parts of the plant (wheat). Some other research workers [4] have also studied the absorption and translocation of Cd by the Arabidopsis halleri, plant known for its hyper cumulative property. Contrary to the previous authors, they found that ${ }^{109} \mathrm{Cd}$ accumulated more in the stems compared to other parts of the plant. Furthermore, their results showed that the addition of ${ }^{65} \mathrm{Zn}$ delayed the toxic effect of $\mathrm{Cd}$.

Others [5-8] have used ${ }^{109} \mathrm{Cd}$ to define the hyper accumulation of Cd by different plants such as Thlaspi caerulescens, Arabidopsis halleri, and Sedum alfredi, superior plants known for their hyper accumulation of $\mathrm{Cd}$. Many others have used the same technique to determine the hyper accumulation which is a property and quality for plants in order to be used in phytoremediation technique [9-14].

\section{Description of the Procedure}

The germination of beans (Phaseolus vulgaris) seeds was achieved in vermiculate during a 12-day period. After this period the plants were transferred into a $100 \mathrm{~mL}$ flask containing nutrient solution and ${ }^{109} \mathrm{Cd}$ with increasing activities: 0.05, 0.1 and 1.0 micro Curie $(\mu \mathrm{Ci})$ respectively. The addition of radioactive cadmium was carried out in a laboratory meeting safety requirements. The samples were then transferred into a specially equipped growing room for periods of 4 to 7 days then analyzed using the scintillation technique. The counting was carried out for roots, stems and leaves.

\section{Description of the Technique}

The solid scintillation technique is one of the techniques used for the detection of radioactive tracers. It is based on the absorption phenomenon by inorganic crystals of alpha, beta or gamma radiations generated by some compounds. These inorganic crystals then emit light flashes that can be detected (counted) by absorbent solid [1]. The counter used in the present study was thallium activated with sodium iodide [NaI (TI)]. This type of counter is commonly used for the detection of gamma radiations due to its short disintegration period. Lithium (UE) or Cs (Tl) may also be used. The disintegration for $\mathrm{Na}$ (TI) is 0.3 microsecond ( $\mu \mathrm{s})$ whereas for $\mathrm{Li}(\mathrm{UE})$ and $\mathrm{Cs}(\mathrm{Tl})$ is 1.1 millisecond (ms). The highest counting yields are obtained with the $\mathrm{NaI}(\mathrm{Tl})$ counters.

\section{Counting}

After a period of four to seven days the plants were washed with demineralised water cut into three parts: roots, stems and leaves then placed into glass tubes and counted for gamma radiation. The remaining part of the nutrient solution was collected and stocked safely in the laboratory. The counting time was fixed at 3 and 5 minutes. The ${ }^{109} \mathrm{Cd}$ gamma spectrum was determined in the range 0 to $120 \mathrm{KeV}$. The ${ }^{109} \mathrm{Cd}$ gamma energy used was roughly $82 \mathrm{KeV}$.

\section{Results and Discussion}

For all the experiment, radioactive ${ }^{109} \mathrm{Cd}$ was added through the plants roots. This technique is recognised as appropriate for the study of the translocation of any element or compound. The results obtained show that ${ }^{109} \mathrm{Cd}$ accumulate more in the roots, the stems then in the leaves (see Tables 1-4). This finding is consistent with that already suggested by $[15,16]$ who studied the barley plant and mentioned that cadmium accumulated preferably in the roots and stems than in the leaves. According to the results presented in the first part it would seem that the leaves react more rapidly to the toxicity of $\mathrm{Cd}$ than the two other parts. This can explain the chlorosis symptom suggesting the $\mathrm{Cd}$ metabolism takes place mainly in the leaves which are more sensitive to $\mathrm{Cd}$ than the other

Table 1. Experiments carried out over a period of 7 days using amount of $\mathrm{Cd}[10 \mathrm{\mu g}-30 \mu \mathrm{g}]$ and variable activity $[0.05 \mu \mathrm{Ci}-1.00 \mu \mathrm{Ci}]$ at fixed counting time 3 minutes.

\begin{tabular}{ccccc}
\hline $\begin{array}{r}\mu \text { g Cd } \\
\text { added }\end{array}$ & $\begin{array}{c}\text { Activity } \\
\mu \mathrm{Ci}\end{array}$ & $\begin{array}{c}\text { Counting } \\
\text { roots }\end{array}$ & $\begin{array}{c}\text { Counting } \\
\text { stems }\end{array}$ & $\begin{array}{c}\text { Counting } \\
\text { leaves }\end{array}$ \\
\hline 10 & 1.00 & 7553 & 1180 & 113 \\
10 & 0.10 & 3071 & 230 & 71 \\
10 & 0.05 & 1849 & 232 & 39 \\
30 & 1.00 & 11458 & 1289 & 578 \\
30 & 0.10 & 2645 & 280 & 60 \\
30 & 0.05 & 1632 & 237 & 77 \\
0 & 1.00 & 13163 & 1390 & 138 \\
\hline
\end{tabular}

Table 2. Experiments carried out over a period of 7 days using amount of $\mathrm{Cd}[10 \mu \mathrm{g}-30 \mu \mathrm{g}]$ and variable activity $[0.05 \mu \mathrm{Ci}-1.00 \mu \mathrm{Ci}]$ at fixed counting time 5 minutes.

\begin{tabular}{ccccc}
\hline $\begin{array}{r}\mu g \text { Cd } \\
\text { added }\end{array}$ & $\begin{array}{c}\text { Activity } \\
\mu \mathrm{Ci}\end{array}$ & $\begin{array}{c}\text { Counting } \\
\text { roots }\end{array}$ & $\begin{array}{c}\text { Counting } \\
\text { stems }\end{array}$ & $\begin{array}{c}\text { Counting } \\
\text { leaves }\end{array}$ \\
\hline 10 & 1.00 & 12677 & 1989 & 198 \\
10 & 0.10 & 4935 & 378 & 122 \\
10 & 0.05 & 2954 & 414 & 67 \\
30 & 1.00 & 18875 & 2046 & 912 \\
30 & 0.10 & 4483 & 546 & 111 \\
30 & 0.05 & 2646 & 461 & 116 \\
\hline
\end{tabular}


Table 3. Experiments conducted using fixed amount of $\mathrm{Cd}$ [30 $\mu \mathrm{g}]$ and variable activity and $[0.25 \mu \mathrm{Ci}-1.00 \mu \mathrm{Ci}]$ at different counting time [3 - 5 minutes].

\begin{tabular}{ccccc}
\hline $\begin{array}{r}\mu g \text { Cd } \\
\text { added }\end{array}$ & $\begin{array}{c}\text { Activity } \\
\mu \mathrm{Ci}\end{array}$ & $\begin{array}{c}\text { Counting } \\
\text { roots }\end{array}$ & $\begin{array}{c}\text { Counting } \\
\text { stems }\end{array}$ & $\begin{array}{c}\text { Counting } \\
\text { Leaves }\end{array}$ \\
\hline \multicolumn{5}{c}{ Counting Time: 3 minutes } \\
\hline 30 & 0.25 & 3277 & 590 & 217 \\
30 & 0.50 & 5408 & 862 & 192 \\
30 & 1.00 & 11128 & 1382 & 319 \\
\hline \multicolumn{6}{c}{ Counting Time: 5 minutes } \\
30 & 0.25 & 5244 & 953 & 333 \\
30 & 0.50 & 9675 & 1498 & 340 \\
\hline
\end{tabular}

Table 4. Experiments Carried out in a shorter period of 4 days using fixed amount of $\mathrm{Cd}[30 \mu \mathrm{g}]$ and fixed activity and $[1.00 \mu \mathrm{Ci}]$ at different counting time [3 - 5 minutes].

\begin{tabular}{ccccc}
\hline $\begin{array}{r}\mu g \text { Cd } \\
\text { added }\end{array}$ & $\begin{array}{c}\text { Activity } \\
\mu \mathrm{Ci}\end{array}$ & $\begin{array}{c}\text { Counting } \\
\text { roots }\end{array}$ & $\begin{array}{c}\text { Counting } \\
\text { stems }\end{array}$ & $\begin{array}{c}\text { Counting } \\
\text { Leaves }\end{array}$ \\
\hline \multicolumn{5}{c}{ Counting Time: 3 minutes } \\
\hline 30 & 1.00 & 9763 & 891 & 228 \\
30 & 1.00 & 12425 & 1104 & 267 \\
30 & 1.00 & 11952 & 1177 & 201 \\
\hline & \multicolumn{5}{c}{ Counting Time: 5 minutes } \\
30 & 1.00 & 23723 & 1692 & 522 \\
30 & 1.00 & 23083 & 1166 & 420 \\
30 & 1.00 & 18782 & 1721 & 574 \\
\hline
\end{tabular}

parts of the bean plant. However, this result can be used later to argue on the effect of $\mathrm{Cd}$ on chlorophyll and causes of the chlorosis. Moreover, one must bear in mind that the vegetable species differ in their response to trace metals since they differ in their nature.

\section{Conclusions}

The use of radioactive ${ }^{109} \mathrm{Cd}$ clearly indicates that this element is preferably absorbed by the bean plant in the order roots $>$ stems $>$ leaves $(\mathrm{R}>\mathrm{S}>\mathrm{L}$ ). The experiments carried out in this study led us to find that at concentrations of Cd considered to be non toxic for the plant [10 $\mu \mathrm{g}$ and $30 \mu \mathrm{g}]$. The counting time had some influence on the translocation of ${ }^{109} \mathrm{Cd}$ in different parts of the plant.

The use of the ${ }^{109} \mathrm{Cd}$ was carried out in order to consolidate the results and findings obtained in previous experiments realized mainly to demonstrate the extent of the toxicity of cadmium on the chlorophyll content, pigment regarded as a mean of pollution alert. From the experiments we have conducted, we can also deduce that the use of radionuclides allows us to obtain clear indications of their importance and helps to track the distribution of toxic elements in different biological systems or other, especially since these are commonly used in food products. The use of radioisotopes has also allowed us to have positive indications to consider using the technique of bio-indication, especially in cases of decontamination and rehabilitation of landfills.

\section{REFERENCES}

[1] M. F. L’Annunziata, "Radiotracers in Agricultural Chemistry,” International Atomic Energy Agency, Vienna, 1979.

[2] J. J. Hart. R. M. Welch, W. A. Norvell and L. V. Kochian, "Transport Interactions between Cadmium and Zinc in Roots of Bread and Durum Wheat Seedlings,” Physiologia Plantarum, Vol. 116, No. 1, 2002, pp. 73-78. doi:10.1034/j.1399-3054.2002.1160109.X

[3] I. Cakmak, R. M. Welch, J. Hart, W. A. Norvell, L. Oztürk and L. V. Kochian, "Uptake and Retranslocation of Leaf-Applied Cadmium $\left({ }^{109} \mathrm{Cd}\right)$ in Diploid, Tetraploid and Hexaploid Wheats," Journal of Experimental Botany, Vol. 51, No. 343, 2000, pp. 221-226. doi:10.1093/jexbot/51.343.221

[4] F. J. Zhao, R. F. Jiang, S. J. Dunham and S. P. McGrath, "Cadmium Uptake, Translocation and Tolerance in the Hyperaccumulator Arabidopsis halleri," New Phytologist, Vol. 172, No. 4, 2006, pp. 646-654. doi:10.1111/j.1469-8137.2006.01867.x

[5] A. J. M. Baker, S. P. McGrath, R. D. Reeves and J. A. C. Smith, "Metal Hyperaccumulator Plants: A Review of the Ecology and Physiology of a Biochemical Resource for Phytoremediation of Metal-Polluted Soils,” In: N. Terry and G. Banuelos, Eds., Phytoremediation of Contaminated Soil and Water, Lewis Publishers, Boca Raton, 2000, pp. 85-107.

[6] B. H. Robinson, M. Leblanc, D. Petit, R. R. Brooks, J. H. Kirkman and P. E. H. Gregg, "The Potential of Thlaspi caerulescens for Phytoremediation of Contaminated Soils," Plant and Soil, Vol. 203, No. 1, 1998, pp. 47-56. doi:10.1023/A:1004328816645

[7] V. Bert, I. Bonnin, P. Saumitou-Laprade, P. deLaguerie and D. Petit, "Do Arabidopsis halleri from Nonmetallicolous Populationsaccumulate Zinc and Cadmium More Effectively than Those from Metallicolous Populations?” New Phytologist, Vol. 155, No. 1, 2002, pp. 47-57. doi:10.1046/j.1469-8137.2002.00432.x

[8] X. E. Yang, X. X. Long, H. B. Ye, Z. L. He, D. V. Calvert and P. J. Stoffella, "Cadmium Tolerance and Hyperaccumulation in a New Znhyperaccumulating Plant Species (Sedum alfredii Hance)," Plant and Soil, Vol. 259, No. 1-2, 2004, pp. 181-189. doi:10.1023/B:PLSO.0000020956.24027.f2 
[9] S. Clemens, M. G. Palmgren and U. Kramer, “A Long Way Ahead: Understanding and Engineering Plant Metal Accumulation,” Trends in Plant Science, Vol. 7, 2002, pp. 309-315. doi:10.1016/S1360-1385(02)02295-1

[10] D. E. Salt, R. D. Smith and I. Raskin, "Phytoremediation," Annual Review of Plant Physiology and Plant Molecular Biology, Vol. 49, 1998, pp. 643-668.

[11] S. P. McGrath and F. J. Zhao, "Phytoextraction of Metals Andmetalloids from Contaminated Soils," Current Opinion in Biotechnology, Vol. 14, No. 3, 2003, pp. 277-282. doi:10.1016/S0958-1669(03)00060-0

[12] E. Lombi, F. J. Zhao, S. P. McGrath, S. D. Young and G. A. Sacchi, "Physiological Evidence for a High-Affinity Cadmium Transporter Highly Expressed in a Thlaspi caerulescens Ecotype," New Phytologist, Vol. 149, No. 1, 2001, pp. 53-60. doi:10.1046/j.1469-8137.2001.00003.x

[13] A. Papoyan and L. V. Kochian, "Identification of Thlaspi caerulescens Genes That May Be Involved in Heavy Metal Hyperaccumulation and Tolerance: Characterization of a Novel Heavy Metal Transporting ATPase,” Plant Physiology, Vol. 136, No. 3, 2004, pp. 3814-3823. doi:10.1104/pp.104.044503

[14] M. Courbot, G. Willems, P. Motte, S. Arvidsson, N. Roosens, P. Verbruggen and N. Saumitou-Laprade, “A Major Quantitative Trait Locus for Cadmium Tolerance in Arabidopsis halleri Colocalizes with HMA4, a Gene Encoding a Heavy Metal ATPase," Plant Physiology, Vol. 144, No. 2, 2007, pp. 1052-1065. doi:10.1104/pp.106.095133

[15] L. M. Cunningham, F. W. Colins and T. C. Hutchinson, "Physiological and Biochemical Aspects of Cd Toxicity in Soybean," International Conference on Heavy Metals in the Environment, Toronto, 1975, p. 97.

[16] J. M. Cutler and D. W. Rains, "Characterization of Cadmium Uptake by Plant Tissue,” Plant Physiology, Vol. 54, No. 1, 1974, pp. 67-71. doi:10.1104/pp.54.1.67 